Business Mathematics 
Also by Jim Dewhurst

MATHEMATICS FOR ACCOUNTANTS AND MANAGERS BUSINESS COST-BENEFIT ANALYSIS

SMALL BUSINESS: Finance and Control (with Paul Burns)

SMALL BUSINESS IN EUROPE (editor with Paul Burns) 


\section{Business Mathematics}

\section{Jim Dewhurst}

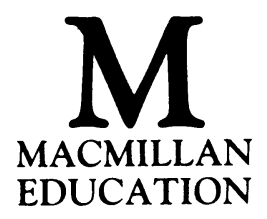


(C) Jim Dewhurst 1988

All rights reserved. No reproduction, copy or transmission of this publication may be made without written permission.

No paragraph of this publication may be reproduced, copied or transmitted save with written permission or in accordance with the provisions of the Copyright Act 1956 (as amended), or under the terms of any licence permitting limited copying issued by the Copyright Licensing Agency, 33-4 Alfred Place, London WC1E 7DP.

Any person who does any unauthorised act in relation to this publication may be liable to criminal prosecution and civil claims for damages.

First published 1988

Published by

MACMILLAN EDUCATION LTD

Houndmills, Basingstoke, Hampshire RG21 2XS

and London

Companies and representatives

throughout the world 


\section{Contents}

Preface

Acknowledgements

xi

xiii

1 Elementary Mathematics

1.1 The concept of number

1.2 Rounding and truncating

1.3 Elementary algebra

1.4 Operator precedence

1.5 Percentages, discounts and mark-ups 7

1.6 Fees and commissions 9

$\begin{array}{lll}1.7 & \text { Simple interest } & 10\end{array}$

1.8 Ratios 11

$\begin{array}{lll}1.9 & \text { Exercises } & 12\end{array}$

2 Computer Number Systems 14

$\begin{array}{ll}2.1 \text { Introduction } & 14\end{array}$

2.2 Binary digits 14

2.3 Binary calculations 16

2.4 Computer codes $\quad 17$

$\begin{array}{lll}2.5 & \text { Octal system } & 17\end{array}$

2.6 Quintal system 20

2.7 Hexadecimal system 20

2.8 Binary coded decimals 22

$2.96,8$ and 16 bits 23

2.10 Decimal-to-binary conversion 23

2.11 Exercises 24

3 Exponents, Progressions, Present value 27

3.1 Introduction 27

3.2 Exponential form 28

3.3 Computer arithmetic 29

3.4 Logarithms 30

3.5 Arithmetic progressions 33

3.6 Geometric progressions 34

3.7 Infinite geometric progressions 35

3.8 Compound interest 35 
3.9 Frequency of conversion $\quad 36$

$\begin{array}{ll}3.10 \text { Present value } & 37\end{array}$

3.11 Interpolation $\quad 38$

$\begin{array}{ll}3.12 \text { Annuities } & 40\end{array}$

3.13 Annuities for perpetuity 41

$\begin{array}{ll}3.14 \text { Deferred annuities } & 42\end{array}$

3.15 Capital investment appraisal 43

3.16 Investment appraisal example $\quad 46$

3.17 Exponential smoothing $\quad 48$

3.18 Exercises $\quad 50$

4 Sets and Relations $\quad 58$

4.1 Defining a set $\quad 58$

4.2 Empty set, universal set, subsets $\quad 59$

$\begin{array}{lll}4.3 & \text { Venn diagrams } & 60\end{array}$

4.4 Union, intersection, complement, difference 60

4.5 Algebra of sets and duality $\quad 62$

$\begin{array}{lll}4.6 & \text { Ordered pairs, products } & 64\end{array}$

$\begin{array}{lll}4.7 & \text { Relations } & 65\end{array}$

$\begin{array}{lll}4.8 & \text { Exercises } & 68\end{array}$

5 Matrices, Vectors and Determinants 72

$\begin{array}{lll}5.1 \text { Matrices } & 72\end{array}$

$\begin{array}{lll}5.2 & \text { Vectors } & 73\end{array}$

5.3 Matrix addition and multiplication $\quad 74$

$\begin{array}{lll}5.4 & \text { Square and identity matrices } & 77\end{array}$

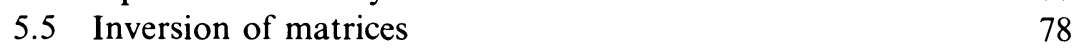

$\begin{array}{lll}5.6 & \text { Determinants } & 79\end{array}$

5.7 Inversion of matrices by determinants 80

5.8 Transformation matrices and their use in matrix inversion $\quad 82$

5.9 Multidimensional arrays $\quad 85$

5.10 Input-output analysis $\quad 86$

$\begin{array}{ll}5.11 \text { Exercises } & 90\end{array}$

6 Algorithms 93

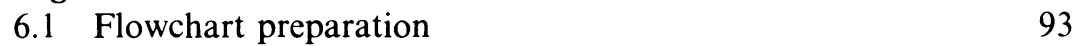

6.2 Flowchart symbols 93

$\begin{array}{lll}6.3 \text { Loops } & 97\end{array}$

$\begin{array}{llr}6.4 & \text { Pseudocode programs } & 97\end{array}$

$\begin{array}{lll}6.5 & \text { Exercises } & 101\end{array}$ 
7 Linear and Higher-power Equations $\quad 105$

$\begin{array}{lll}7.1 & \text { Use of equations } & 105\end{array}$

$\begin{array}{lll}7.2 & \text { Linear equations } & 105\end{array}$

$\begin{array}{lll}7.3 \text { Gaussian elimination } & 108\end{array}$

$\begin{array}{lll}7.4 & \text { Matrix inversion method } & 111\end{array}$

$\begin{array}{ll}7.5 & \text { Iterative method solution of equations } \\ 7.6 & \text { Cubic equations }\end{array}$

$\begin{array}{ll}7.6 \text { Cubic equations } & 116\end{array}$

$\begin{array}{ll}7.7 \text { Power of four } & 117\end{array}$

$\begin{array}{lll}7.8 & \text { Other iterative methods } & 118\end{array}$

$\begin{array}{lll}7.9 & \text { Exercises } & 119\end{array}$

8 Graphs $\quad 122$

$\begin{array}{lll}8.1 \text { Introduction } & 122\end{array}$

8.2 Axes and co-ordinates 122

$\begin{array}{ll}\text { 8.3 Graph of a linear equation } & 123\end{array}$

$\begin{array}{ll}\text { 8.4 Points lying on either side of a line } & 125\end{array}$

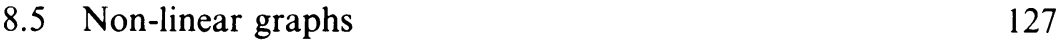

$\begin{array}{ll}8.6 \text { The circle } & 128\end{array}$

$\begin{array}{lll}8.7 & \text { The hyperbola } & 130\end{array}$

$\begin{array}{ll}\text { 8.8 The exponential function } & 132\end{array}$

8.9 Graphs and business problems 133

8.10 Economic approach to investment, financing and
dividend decision making

8.11 Exercises 143

9 Calculus $\quad 147$

$\begin{array}{lll}9.1 \text { Differentiation } & 147\end{array}$

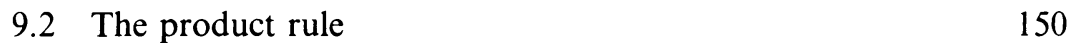

$\begin{array}{lll}9.3 & \text { The quotient rule } & 152\end{array}$

9.4 The function of a function (or chain) rule 152

9.5 The exponential and logarithmic functions 153

9.6 Maxima and minima 153

$\begin{array}{llr}9.7 & \text { Differentials } & 159\end{array}$

$\begin{array}{lll}9.8 & \text { The integral calculus } & 159\end{array}$

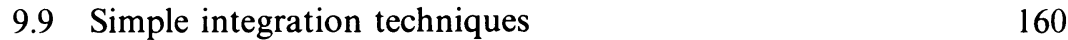

$\begin{array}{ll}9.10 \text { Calculation of the area under a curve } & 162\end{array}$

$\begin{array}{ll}9.11 \text { Partial differentiation } & 164\end{array}$

$\begin{array}{ll}9.12 \text { Total differentials } & 167\end{array}$

9.13 Three-dimensional maxima and minima 168

$\begin{array}{ll}9.14 \text { Maxima and minima subject to constraint } & 170\end{array}$

$\begin{array}{ll}9.15 \text { Multivariate functions and multiple constraints } & 171\end{array}$

$\begin{array}{ll}9.16 \text { Elasticity of demand } & 172\end{array}$

$\begin{array}{ll}9.17 \text { Marginal analysis } & 173\end{array}$

9.18 The economic order quantity model 173

$\begin{array}{ll}9.19 \text { Exercises } & 178\end{array}$ 
10 Probability $\quad 186$

$\begin{array}{lll}10.1 & \text { Probability theory } & 186\end{array}$

$\begin{array}{lll}10.2 & \text { Finite probability spaces } & 187\end{array}$

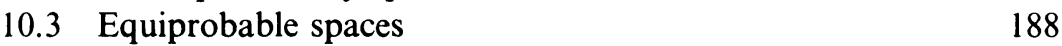

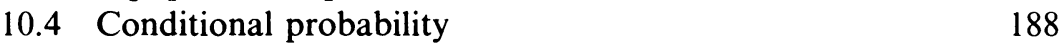

$\begin{array}{lll}10.5 & \text { Independence } & 190\end{array}$

10.6 Probability and combinatorial analysis 191

$\begin{array}{lll}10.7 & \text { Inventory stock out costs } & 191\end{array}$

Risk and uncertainty in business forecasting and
decision making

$\begin{array}{ll}10.9 \text { Markov chains } & 203\end{array}$

10.10 Absorbing states 206

10.11 Combinatorial analysis $\quad 208$

$\begin{array}{ll}10.12 \text { Permutations } & 209\end{array}$

$\begin{array}{ll}10.13 \text { Combinations } & 211\end{array}$

$\begin{array}{ll}10.14 \text { Binomial theorem } & 212\end{array}$

$\begin{array}{ll}10.15 \text { Exercises } & 212\end{array}$

11 Regression Analysis $\quad 220$

$\begin{array}{ll}11.1 \text { Introduction } & 220\end{array}$

$\begin{array}{lll}11.2 & \text { Simple regression } & 221\end{array}$

11.3 Formulae for the line of best fit or regression line 223

11.4 Application of the formulae for the line of best fit 224

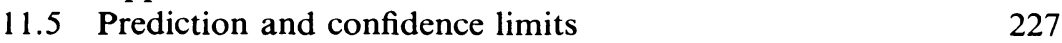

$\begin{array}{lll}11.6 & \text { Multiple regression } & 228\end{array}$

11.7 Interpretation of the statistical data 232

11.8 Application of the multiple regression formulae 236

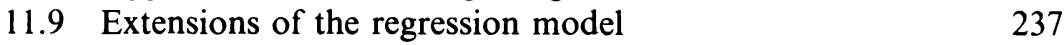

$\begin{array}{ll}11.10 \text { Dummy variables } & 238\end{array}$

$\begin{array}{ll}11.11 \text { Business uses of regression analysis } & 239\end{array}$

$\begin{array}{ll}11.12 \text { Discriminant analysis } & 240\end{array}$

$\begin{array}{ll}11.13 Z \text { score analysis } & 242\end{array}$

11.14 Exercises $\quad 243$

12 Linear Programming (Robert Ashford) 246

$\begin{array}{lll}12.1 \text { Introduction } & 246\end{array}$

$\begin{array}{ll}12.2 \text { A simple problem } & 246\end{array}$

$\begin{array}{lll}12.3 & \text { Some basic concepts } & 248\end{array}$

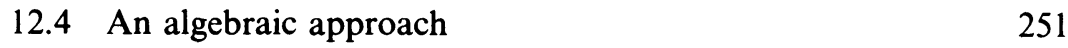

12.5 The simplex method 253

$\begin{array}{lll}12.6 & \text { The simplex tableau } & 259\end{array}$

$\begin{array}{lll}12.7 & \text { Exercises } & 264\end{array}$ 
13 Sensitivity Analysis, Duality and the Transportation

Algorithm (Robert Ashford)

13.1 Sensitivity analysis or ranging

13.2 Duality

13.3 The transportation algorithm

13.4 Integer programming

13.5 Exercises

290

Appendix $A$ Tables

A.1 Logarithms

A.2 Present value tables

301

A.3 Annuity tables

302

A.4 Probability tables

303

Appendix B Solutions to Exercises

304

Appendix $C$ Worked Answers

310

Further Reading

328

Index 


\section{Preface}

This book is intended for those students and managers whose basic knowledge of mathematics can best be described as being broadly equivalent to the (old!) 'O' level.

The approach used in this book is based partly on 'traditional' maths and partly on modern maths. This reflects the view of the author that both have advantages, and that acting together they can provide a very powerful base. This approach is also desirable for other, more pragmatic reasons. First, readers will have widely differing mathematical backgrounds; second, many professional, managerial, accountancy and banking examinations require an understanding of both these approaches. Further, most techniques these days will be implemented with the aid of a suitable computer program. This book may therefore be seen as being based on the integration of traditional maths with modern maths through the technique of computers.

The material has been divided into thirteen chapters and they have been written so that they are to an extent independent of each other.

Each chapter starts with the relevant mathematics and at the end covers appropriate applications to the business situation. There are exceptions to this, since sometimes the business application is more suitably dealt with in the body of the text. An example of this is in Chapter 13, where the transportation algorithm is an integral part of the mathematical text and is treated as such.

Answers are given for most of the quantitative questions (Appendix B); in addition fully-worked answers (the author's responsibility) have been provided for some questions (Appendix C). The intention here has been to provide one of these worked answers for a typical examination question in each of the main areas of the subject.

Except where necessary for a proper appreciation of the business techniques this book does not concern itself with statistics. Plenty of books have been written solely on this subject. There have, however, been some 'demarcation' problems! These have been particularly difficult in the general area of what might be described as 'mathematically-based operational research methods'. In order to help bridge this gap a short selected bibliography of books in this area has been provided. Because of their practical and examination importance regression analysis and linear programming have been included.

Chapters 12 and 13 have been written by Robert Ashford (of the School of Industrial and Business Studies, University of Warwick) who is a leading authority in the field of linear programming. 
Many readers will certainly be working for university, professional, and other examinations. This book covers the mathematical requirements for the examinations of the Chartered Institute of Cost and Management, the Chartered Institute of Public Finance and Accounting, the Institute of Banking, the Chartered Insurance Institute, and the British Institute of Management.

Sometimes, in this book, sexist words and phrases may be used, though hopefully only where general usage sanctions it.

Finally, my thanks to Louise Harris, Shirley Clarke, Robert Ashford, Phillip Moon and Graham Jones. 


\section{Acknowledgements}

The author and publishers acknowledge with thanks permission from professional bodies including the Institute of Chartered Accountants in England and Wales, the Chartered Institute of Cost and Management Accountants, the Chartered Insurance Institute and the Chartered Institute of Public Finance and Accounting to reproduce questions from their past examination papers. 